\title{
Analyzing the effect of customer loyalty on virtual marketing adoption based on theory of technology acceptance model
}

\author{
Peyman Ghafari Ashtiani $^{\mathrm{a}}$, Atefeh Parsayan ${ }^{b^{*}}$ and Moein Mohajerani ${ }^{\mathrm{b}}$
}

${ }^{a}$ Department of Management, Arak Branch, Islamic Azad University, Arak, Iran

${ }^{b}$ Master of EMBA, Department of Management, Arak Branch, Islamic Azad University, Arak, Iran

\section{H R O N I C L E}

Article history:

Received January 5, 2016

Received in revised format April 15,2016

Accepted July 1, 2016

Available online

July 7, 2016

Keywords:

Customer loyalty

Viral marketing

Theory of technology acceptance

model

$T A M$

\section{A B S T R A C T}

\begin{abstract}
One of the most advantages of the internet and its expansion is probably due to its easy and low cost access to unlimited information and easy and fast information exchange. The accession of communication technology for marketing area and emergence of the Internet leads to creation and development of new marketing models such as viral marketing. In fact, unlike other marketing methods, the most powerful tool for selling products and ideas are not done by a marketer to a customer but from a customer to another one. The purpose of this research is to analyze the relationship between customers' loyalty and the acceptance of viral marketing based on the theory of technology acceptance model (TAM) model among the civil engineers and architects who are the members of Engineering Council in Isfahan (ECI). The research method is descriptive-survey and it is applicable in target. The statistical population includes civil engineers and architects who are the members of Engineering Council in Isfahan including 14400 members. The sample size was determined 762 members based on Cochran sampling formula, the sample was selected as accessible. The data was collected by field method. Analyzing the data and recent research hypothesis, the data was extracted from the questionnaires. Then, all the data was analyzed by computer and SPSS and LISREL software. According to the results of the data, the loyalty of the civil engineers and architects members of ECI was associated with the acceptance and practical involvement of viral marketing.
\end{abstract}

\section{Introduction}

The easy and low cost access to unlimited data and easy exchange of information can probably be the most advantages of the Internet and its surprising expansion. The accession of information technology to marketing and the emergence of Internet can lead to creation and expansion of new marketing models such as viral marketing. Information exchange is the leaven of viral marketing (Masouleh et al., 2012). There are several methods and tools for realization of viral marketing. One type of viral marketing is based on email communication (Hubona \& Burton, 2003), which is more examined in this research.

* Corresponding author.

E-mail address: parsayanatefeh@yahoo.com (A. Parsayan) 
There are several factors involved in the decision of the applicants for sending or not sending of these email messages and as the result involvement or dis-involvement in viral marketing. The target of this research is to investigate the role of loyalty in this case (Day, 1969; Ho \& Dempsey, 2010). This paper analyzes the effect of customer loyalty on virtual marketing adoption based on theory of technology acceptance model. The selected statistical population of this research includes civil engineers and architects of Engineering Council of Isfahan. The findings of this research can directly be used for improvement of viral marketing systems especially in construction industry.

\section{The proposed study}

The entrance of information technology in marketing and revelation of the internet resulted to creation and development of new models of marketing such as viral marketing. One of the most common methods of viral marketing is based on resending the received email messages by applicants. These email messages can be made by users or designed by a company but the whole or part of these emails contains advertising messages directly or indirectly.

In this paper, Technology Acceptance Model (TAM) is selected as the basic model of this research to develop and reflect the reaction and viral features. The structure of the proposed model is called loyalty, which increases acceptance of customers. One of the aspects of loyalty is recommendation of previous customers of organizations to potential customers for using the products of organization. Also, designing messages can decrease or increase the loyalty of customers to a brand (Jacoby \& Chestnut, 1978 ) and plays a key role in sending this message to others. This type of application can also reduce or increase the loyalty. Thus, it seems that loyalty is one of the effective factors for the success of viral marketing strategies. In this research, we analyze the effects of customer loyalty on the acceptance of viral marketing based on TAM model among the civil engineers and architects of the members of Engineering Council of Isfahan (ECI).

\subsection{Research Objectives}

Primary Objectives: To determining the relationship between customer loyalties with the acceptance of Viral Marketing based on TAM model among the civil engineers and architects of the members of Engineering Council of Isfahan.

\section{Secondary objectives:}

The secondary objective of this study is to

1. To determine the relationship between perceived usefulness of customer with his/her loyalty in involving in viral marketing among the ECI civil engineers and architectures members.

2. To determine the relation of loyalty of customers with their attitudes for involving in viral marketing among the ECI civil engineers and architectures members.

3. To determine the relation of loyalty of customers with their intention (Fishbein \& Ajzen, 1975) for involving in viral marketing among the ECI civil engineers and architectures members.

4. To determine the relationship between the clients perceived ease of use and their perceived usefulness for involving in viral marketing among the ECI civil engineers and architectures members. 5. To determine the relationship between the clients perceived usefulness with their attitudes for involving in viral marketing among the ECI civil engineers and architectures members.

6. To determine the relationship between the clients perceived ease of use and their attitudes for involving in viral marketing among the ECI civil engineers and architectures members.

7. To determine the relationship between the clients perceived usefulness with their intentions for involving in viral marketing among the ECI civil engineers and architectures members. 
8. To determine the relationship between the clients perceived ease of use and their intentions for involving in viral marketing among the ECI civil engineers and architectures members.

9. To determine the relationship between the customer's intention with their actual use (acceptance) in viral marketing among the ECI civil engineers and architectures members.

\subsection{Research Application}

1. The findings of this research can be used for expansion of viral marketing system specifically in construction industry. According to the strong competition between the providers of construction industry and due to the necessary cost and time for developing of viral marketing system, ensuring that the addressed people use it is so essential.

2. The findings of this research can contain practical suggestions and recommendations for the providers of construction industry on how to involve customers in the process of viral marketing based on the cultural and social parameters of the country and the features of professional market and the customers of construction industry.

3. In this research, the main focus is on customer satisfaction for introducing the product to others for developing viral marketing culture and for decreasing the costs of advertising of companies.

The main advantage of viral marketing is that marketers can create customers by almost zero cost, and the mode is changed from "marketer-consumer" to "consumer-consumer" (Jan Nesar Ahmadi \& Ghafari, 2007). In fact, on the contrary with other marketing methods, the most influence in selling products and ideas is not through a marketer to a customer but from a customer to another customer. On the other hand, social networks have moved towards the web. Thus, there is a suitable field for applying viral marketing. The innovation of this research is that the subject is analyzed from the perspective of a customer. The aim of this research is to analyze the relationship of loyalty with viral marketing among the civil engineers and architects of Engineering Council of Isfahan in city of Isfahan, Iran.

\section{Theoretical framework and conceptual model of research}

During the recent decades, the perceived usefulness and facility in usage are considered as determining factors in the acceptance of information systems and information technology and communication among customers exclusively. These organizations are the foundations of acceptance of technology. Technology Acceptance Model (TAM) is one of the models which is widely welcomed by users and customers for explaining the effective factors on the acceptance of information systems and information technology and communication. Several researches have confirmed the validity of TAM in the field of acceptance of information technology and communication (Venkatesh \& Davis, 2000; Roberts \& Henderson, 2000; Davis et al., 1989).

TAM was selected as basic structure of this research, and we intend to develop it to reflect the reactive and viral features and offer another structure as customer loyalty in this research. Davis (1989) offered this model to determine and predict the adaptation and application of information technology. The basis of TAM is that the perceiving of usefulness and facility in usage are the key factors for determining the adaptation of innovative technology. Davis considers the perceiving of usefulness to the extent that technology helps the improvement of performance while the perceiving of facility in usage is the belief of people about this fact that the usage of one technology is easy and simple (Davis, 1989). 
According to Davis's Technology Acceptance Model:

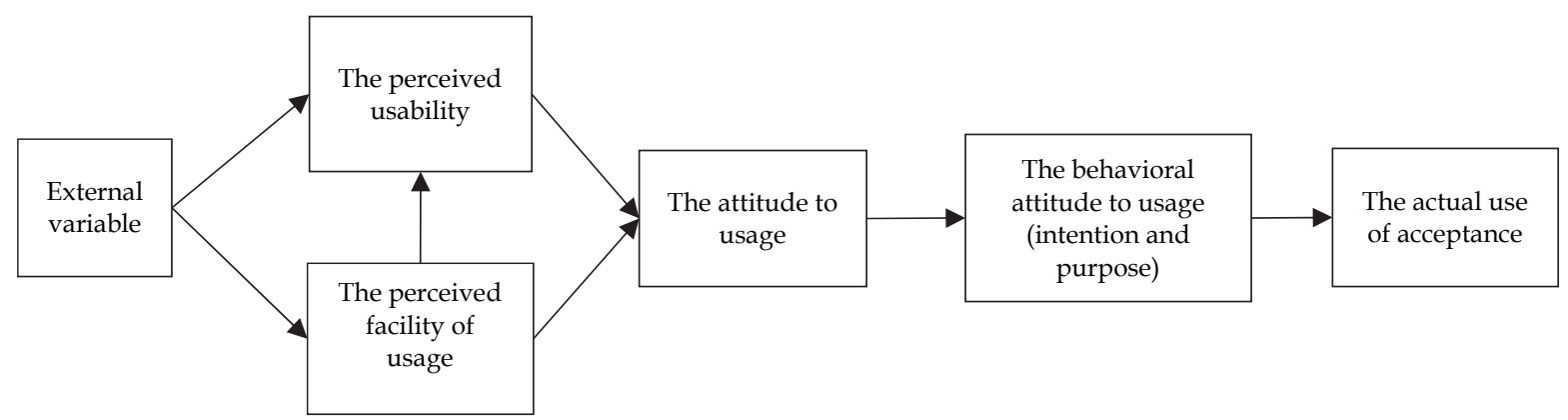

Fig. 1. Davis's Technology Acceptance Model

The proposed model of this paper is as follows,

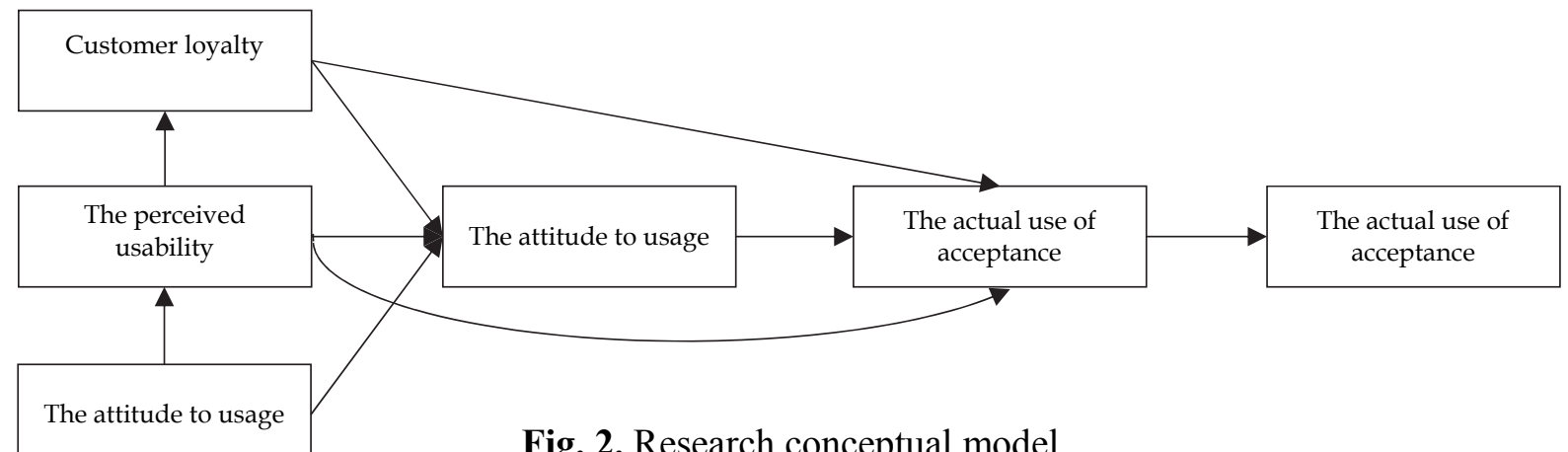

Fig. 2. Research conceptual model

\subsection{Hypothesis}

The proposed study of this paper considers the following hypotheses,

1) The perceived usefulness of customer is associated with his/her loyalty for involving in viral marketing.

2) Customer loyalty is associated with his/her attitude for involvement in viral marketing.

3) Customer loyalty is associated with his/her intention for involvement in viral marketing.

4) The perceived facility of usage of customer is associated with his/her perceived usefulness for involvement in viral marketing.

5) The perceived usefulness of customer is associated with his/her attitude for involvement in viral marketing.

6) The perceived facility of usage of customer is associated with his/her attitude for involvement in viral marketing.

7) The perceived usefulness of customer is associated with his/her intention for involvement in viral marketing.

8) The perceived facility of usage of customer is associated with his/her intention for involvement in viral marketing.

9) The intention of customer is associated with his/her actual usage (acceptance) in viral marketing.

\subsection{Research Methodology}

Research methodology of this study is Descriptive-survey in which the relationships of variables are analyzed based on research purpose. 


\subsection{Classification Based on Objectives}

The method of this research based on its objective is practical since its findings can be used in the face of market practices.

\subsection{Statistical Population}

The statistical population of this study consists of 14400 civil engineers and architects who are the member of Engineering Council of Isfahan.

\subsection{Statistical Sample}

A) Sample size

Therefore we could use the following formula to calculate the minimum number of sample size,

$$
n=\frac{N \times z_{\alpha / 2}^{2} \times p \times q}{\varepsilon^{2} \times(N-1)+z_{\alpha / 2}^{2} \times p \times q},
$$

where $N$ is the population size, $p=1-q$ represents the yes/no categories, $z_{\alpha / 2}$ is CDF of normal distribution and finally $\varepsilon$ is the error term. Since we have $p=0.5, z_{\alpha / 2}=1.96$ and $N=14400$, the number of sample size is calculated as $n=762$.

\subsection{The method and tools of data collection}

The data of this research was collected in field. An anonymous questionnaire was used to collect data and achieve the objectives which were completed by civil engineers and architects of the members of Engineering Council of Isfahan. The research questions were put in the format of Questionnaire items. Each item of questionnaire, based on the major objective and considered questions and the answer of each question, is a step to realization the main objective of the research. This questionnaire includes 71 items as explained in Table 1.

Table 1

Variables and numbers of items of questionnaire

\begin{tabular}{ccc}
\hline Row & The questioned variable & The number of item of questionnaire \\
\hline 1 & The perceived usefulness & $1-4$ \\
2 & The perceived facility of usage & $5-7$ \\
3 & Attitude to usage & $8-10$ \\
4 & Behavioral intention to use (desire to purchase) & $11-13$ \\
5 & Customer loyalty & $14-17$ \\
6 & Actual usage (acceptance) & $18-20$ \\
\hline
\end{tabular}

In this research, the measurement is Ordinal Scale and the employed spectrum is Likert Scale (from completely agree with 0 score to completely disagree with 5 score). The research questionnaire validity was assessed by experts and managers. Thus, it has suitable validity or it is valid, in another word. Cronbach's alpha coefficients was used for assessment of reliability of the questionnaire. Cronbach's alpha coefficients was measure 0.95 by computer and SPSS software, Distributing all the questionnaires, Cronbach's alpha coefficients was measured for the fully completed questionnaires and analyzed. The results were achieved as Table 2. Considering the fact that the minimum Cronbach's alpha coefficients for research questionnaires is $0.70 \%$, the achieved Cronbach's alpha coefficients is more than that and suitable. 
Table 2

Cronbach's alpha coefficients

\begin{tabular}{ccc}
\hline Row & The questioned variable & Cronbach's alpha coefficients \\
\hline 1 & The perceived usefulness & 0.871 \\
2 & The perceived facility of usage & 0.838 \\
3 & Attitude to usage & 0.889 \\
4 & Behavioral intention to use (desire to purchase) & 0.891 \\
5 & Customer loyalty & 0.722 \\
6 & Actual usage (acceptance) & 0.906 \\
7 & Total Questionnaire & 0.941 \\
\hline
\end{tabular}

\subsection{Research Variables}

The research variables can be classified as follow:

Latent exogenous variables which there is one exogenous variable in this research which is the perceived facility of usage. Latent endogenous variables include: the perceived usefulness, Customer loyalty, attitude to usage, behavioral tendency to usage (intention), and actual usage (acceptance). The observed variables related to Exogenous variables include the perceived facility of usage (Q5, Q6, Q7, Q8) and observed Latent endogenous variable include the perceived usefulness(Q1, Q3, Q3, Q4), customer loyalty (Q17, Q16, Q15, Q14), attitude to usage (Q10, Q9, Q8 ), behavioral tendency to usage or intention (Q13, Q12, Q11) and actual usage or acceptance (Q20, Q19, Q18 ).

\subsection{Data Analysis Method}

For analyzing the data and testing the research hypothesis of this research, inferential statistics and structural equation modeling were used. Structural equation modeling is statistical models for analyzing linear equations between Latent variables (not observed) and obvious variables (observed). Researchers can approve or disapprove the adaptability of these Hypothetical structures, which is generally called model (with less accuracy) and causative models, with contesting data by the use of these models (Houman, 2008). For analyzing the statistical data of this study, first the data was extracted from the questionnaires and set in the mother table. Then, all the data was analyzed by computer and SPSS and LISREL software.

\section{The necessities of usage of Structural equation modeling}

A) Since the major goal of Structural equation modeling is to analyze latent variables, specifically the analysis of causative relation of these variables, this method has more ability compared with other analytical methods.

B) Structural equation modeling can estimate the interconnected relationship between internal dependent and independent variables.

C) There are some software packages such as LISREL to estimate the parameters of models rapidly and accurately, and evaluate the constructed model.

\subsection{Assessment of Research Model}

When the data of sample group is changed into correlation matrix or covariance, and it is described by a series of regression equation, this model can be processed and analyzed (by some available software) in the societies which the samples are driven. Some assessments of parameters of that model including coefficient of the path and error sentences and some measures for its suitability to the sample data is achieved (Houman, 2008). Fig. 3 illustrates the standard model which is achieved by LISREL software. 
As it is indicated in the diagram, seven latent variables (the perceived facility of usage, the perceived usefulness, customer loyalty, the attitude to usage, behavioral attitude to usage and actual use) and their measurement indicators are shown.

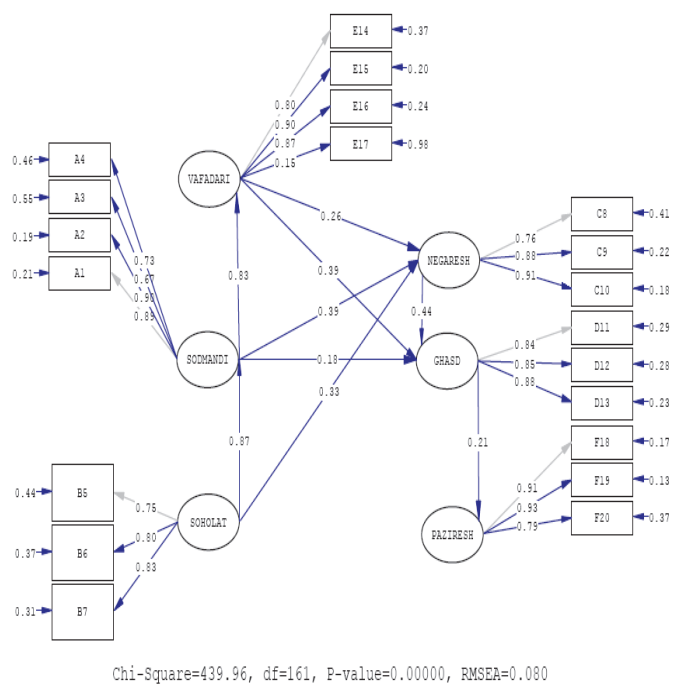

Fig. 3. Standard Research Model by the use of LISREL software

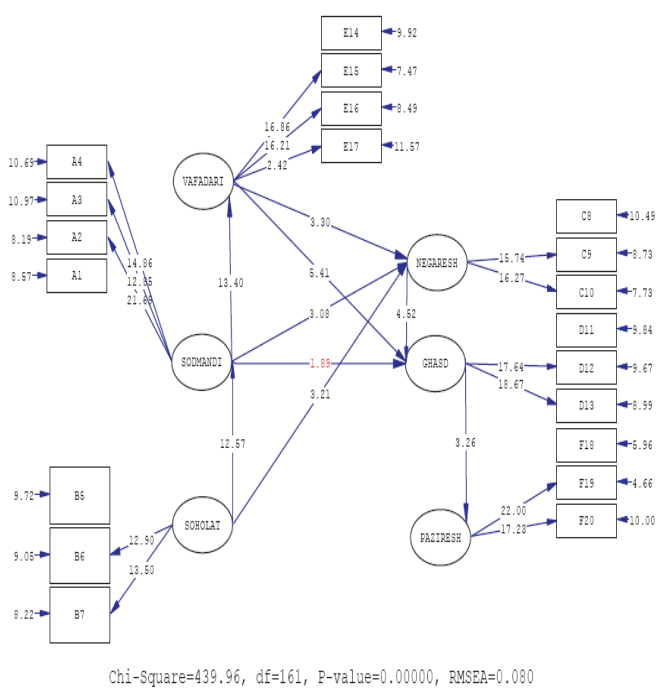

Fig. 4. Model in Significant state with t-value

\subsection{Analysis of model congruency}

For analyzing the fitness of this model, some indicators such as Chi-Square, Root Mean Square Error of Approximation (RMSEA), P-value, indicators of GFI and AGFI were used. Among the Fitness indexes, generally, RMSEA is an Optimal Index and CFI is considered as the best index. Fitness indexes are generally between zero and one. The coefficients which are more than $90 \%$ are considered acceptable though it is optional as $p=0.05$. In this research, the measured amount for index RMSEA equals to 0.080 and for parameters of $\mathrm{GFI}=0.86, \mathrm{IFI}=0.97, \mathrm{CFI}=0.97$, and Chi-Square $=2.732$ which indicate acceptability of this model. The offered indexes and their comparison with the optimal model shows a suitable fitness of the model. One of the important things in this model fitness is that fitness index confirms the structure of the model but it never indicates that this is the unique valid model.

\subsection{The results of research hypothesis}

In this section, the significance of the numbers achieved by the model is studied; in terms of significance of numbers, it can be said that as we are testing the hypothesis by 0.95 assurance and 0.5 percent error, the numbers which are significant for $t$ are more than -1.96 and +1.96 . This means that if in this test a number is between -1.96 and +1.96 , it is insignificant. In model number 1 , the numbers achieved for $t$ test are meaningful, and we can analyze the causative factor (measurement indicators with latent variable) and effects (latent variables with each other). According to what is mentioned in the table and figure, the achieved model has suitable status. Thus, according to the model in significance level (Fig. 3) and Standard estimation model (Fig. 4), the analysis or research hypothesis is based on Table 3. 
Table 3

Regression weights- Loading factor model

\begin{tabular}{|c|c|c|c|c|c|c|c|}
\hline Predictors variables & & $\begin{array}{l}\text { Instant predictor } \\
\text { variables }\end{array}$ & $\begin{array}{l}\text { Estimated } \\
\text { values }\end{array}$ & $\begin{array}{l}\text { Standard } \\
\text { values }\end{array}$ & Error & $\begin{array}{c}\mathrm{T} \\
\text { statistics }\end{array}$ & $\begin{array}{c}\text { Test } \\
\text { Result }\end{array}$ \\
\hline $\begin{array}{c}\text { The perceived facility of } \\
\text { usage }\end{array}$ & $y$ & & 0.30 & 0.33 & 0.09 & 3.21 & Confirmed \\
\hline The perceived usefulness & $\rightarrow$ & Attitude to usage & 0.36 & 0.39 & 0.12 & 3.08 & 0.84 Confirmed \\
\hline Customer loyalty & $\pi$ & & 0.25 & 0.26 & 0.08 & 3.30 & Confirmed \\
\hline The perceived usefulness & $y$ & & 0.18 & 0.18 & 0.07 & 1.89 & Confirmed \\
\hline Customer loyalty & $\rightarrow$ & Behavioral attitude to usage & 0.40 & 0.39 & 0.09 & 5.41 & 0.93 Confirmed \\
\hline Attitude to usage & $\pi$ & & 0.46 & 0.44 & 0.10 & 4.52 & Confirmed \\
\hline $\begin{array}{l}\text { The perceived facility of } \\
\text { usage }\end{array}$ & $\rightarrow$ & $\begin{array}{l}\text { The perceived } \\
\text { usefulness }\end{array}$ & 0.86 & 0.87 & 0.07 & 12.57 & 0.75 Confirmed \\
\hline The perceived usefulness & $\rightarrow$ & Customer loyalty & 0.78 & 0.83 & 0.06 & 13.40 & 0.69 Confirmed \\
\hline Attitude to usage & $\rightarrow$ & $\begin{array}{c}\text { Behavioral attitude to } \\
\text { usage }\end{array}$ & 0.46 & 0.44 & 0.10 & 4.52 & 0.93 Confirmed \\
\hline $\begin{array}{c}\text { Behavioral attitude to } \\
\text { usage }\end{array}$ & $\rightarrow$ & Actual usage & 0.26 & 0.21 & 0.08 & 3.26 & 0.24 Confirmed \\
\hline The perceived usefulness & $\rightarrow$ & A1 & 1.00 & 0.89 & -- & -- & 0.79 \\
\hline The perceived usefulness & $\rightarrow$ & $\mathrm{A} 2$ & 1.12 & 0.98 & 0.05 & 21.69 & 0.81 \\
\hline The perceived usefulness & $\rightarrow$ & A3 & 0.89 & 0.67 & 0.07 & 12.85 & 0.45 \\
\hline The perceived usefulness & $\rightarrow$ & A4 & 0.89 & 0.73 & 0.06 & 14.86 & 0.54 \\
\hline $\begin{array}{c}\text { The perceived facility of } \\
\text { usage }\end{array}$ & $\rightarrow$ & B5 & 1.00 & 0.75 & -- & -- & 0.56 \\
\hline $\begin{array}{c}\text { The perceived facility of } \\
\text { usage }\end{array}$ & $\rightarrow$ & B6 & 1.10 & 0.80 & 0.09 & 12.90 & 0.63 \\
\hline $\begin{array}{c}\text { The perceived facility of } \\
\text { usage }\end{array}$ & $\rightarrow$ & B7 & 1.07 & 0.83 & 0.08 & 13.50 & 0.69 \\
\hline Attitude to usage & $\rightarrow$ & $\mathrm{C} 8$ & 1.00 & 0.76 & -- & -- & 0.59 \\
\hline Attitude to usage & $\rightarrow$ & C9 & 1.25 & 0.88 & 0.08 & 15.74 & 0.78 \\
\hline Attitude to usage & $\rightarrow$ & $\mathrm{C} 10$ & 1.27 & 0.91 & 0.08 & 16.27 & 0.82 \\
\hline $\begin{array}{c}\text { Behavioral attitude to } \\
\text { usage }\end{array}$ & $\rightarrow$ & D11 & 1.00 & 0.84 & -- & -- & 0.71 \\
\hline $\begin{array}{c}\text { Behavioral attitude to } \\
\text { usage }\end{array}$ & $\rightarrow$ & D12 & 1.04 & 0.85 & 0.06 & 17.64 & 0.72 \\
\hline $\begin{array}{c}\text { Behavioral attitude to } \\
\text { usage }\end{array}$ & $\rightarrow$ & D13 & 1.10 & 0.88 & 0.06 & 18.67 & 0.77 \\
\hline Customer loyalty & $\rightarrow$ & E14 & 1.00 & 0.80 & -- & -- & 0.63 \\
\hline Customer loyalty & $\rightarrow$ & E15 & 1.08 & 0.90 & 0.06 & 16.86 & 0.80 \\
\hline Customer loyalty & $\rightarrow$ & E16 & 1.00 & 0.87 & 0.06 & 16.21 & 0.76 \\
\hline Customer loyalty & $\rightarrow$ & E17 & 0.21 & 0.15 & 0.09 & 2.42 & 0.22 \\
\hline Actual usage & $\rightarrow$ & F18 & 1.00 & 0.91 & -- & -- & 0.83 \\
\hline Actual usage & $\rightarrow$ & F19 & 1.05 & 0.93 & 0.05 & 22.00 & 0.87 \\
\hline Actual usage & $\rightarrow$ & F20 & 0.94 & 0.79 & 0.05 & 17.23 & 0.63 \\
\hline
\end{tabular}




\subsection{Results based on hypotheses}

In this research, the relation of customer loyalty and acceptance of viral marketing based on TAM model was analyzed among the civil engineers and architects of members of Engineering Council of Isfahan. According to the analysis or research result data, the analysis of each of the hypothesis is as follow:

1. The perceived usefulness of customer is related to customer for engaging in viral marketing. Since Factor variable path of the perceived usefulness of customer is calculated on the variable of customer loyalty with $t$ value, this statistic is significant with 0.95 . Thus, the first hypothesis is confirmed. Thus, the perceived usefulness of civil engineers and architects of engineering council of Isfahan is related to their loyalty for engaging in viral marketing. Thus, as the perceived usefulness is more, it can be expected that their royalty for involvement in viral marketing increases.

2. Customer loyalty is related to his/her attitude for involvement in viral marketing.

Since the factor variable path of customer loyalty to his/her attitude for involvement in viral marketing is calculated with $t$ value, this statistic is significant with 0.95 . Thus, the second hypothesis is confirmed and the loyalty of civil engineers and architects of engineering council of Isfahan is related to their attitude for engaging in viral marketing. Thus, Construction companies can effect on their attitude for engaging in viral marketing by providing some conditions to increase their loyalty.

3. Customer loyalty is related to his intention for involvement in viral marketing. Since Factor variable path of customer loyalty to his intention for involvement in viral marketing is calculated with $t$ value, this statistic is significant with 0.95 . Thus, the third hypothesis is confirmed. Thus, the loyalty of civil engineers and architects of engineering council of Isfahan is related to their intention for engaging in viral marketing. Thus, Construction companies can effect on their intention for engaging in viral marketing by providing some conditions to increase their loyalty.

4. The perceived facility of usage of customer is related to his/her perceived usefulness for involvement in viral marketing. Since Factor variable of path of the perceived facility of usage of customer to his/her intention for involvement in viral marketing is calculated with $t$ value, this statistic is significant with 0.95.Thus, the fourth hypothesis is confirmed. Thus, as the perceived facility of usage increases, they expect to understand more usefulness in engaging in viral marketing. This finding is in parallel with Pavlov et al.'s studies (2005) which showed that facility of usage is effective on the perceived usefulness in electronic commerce.

5. The perceived usefulness of customer is related to his/her attitude for involvement in viral marketing. Since Factor variable path of perceived usefulness of customer to his/her attitude for involvement in viral marketing is calculated with $t$ value, this statistic is significant with 0.95 and the fifth hypothesis is confirmed. Thus, the perceived usefulness of civil engineers and architects of engineering council of Isfahan is related to their attitude for engaging in viral marketing. This finding is in parallel with Davis studies (1989) which showed that perceived usefulness of customer from a technology is effective on their attitude toward that technology.

6. The perceived facility of usage of customer is related to his/her attitude for involvement in viral marketing. Since Factor variable path of perceived facility of usage of customer to his/her attitude for involvement in viral marketing is calculated with $t$ value, this statistic is significant with 0.95 and the sixth hypothesis is confirmed. Thus, the perceived facility of usage of civil engineers and architects of engineering council of Isfahan is related to their attitude for engaging in viral marketing. This finding is in parallel with Davis studies (1989) which showed that perceived facility of usage of customer from a technology is effective on their attitude toward that technology. 
7. The perceived usefulness of customer is related to his/her intention for involvement in viral marketing. Since Factor variable path of perceived usefulness of customer to his/her intention for involvement in viral marketing is calculated with $t$ value, this statistic is significant with 0.90 and the seventh hypothesis is confirmed. Thus, the perceived usefulness of civil engineers and architects of engineering council of Isfahan is related to their intention for engaging in viral marketing. This finding is in parallel with Pavlov et al.'s studies (2005) which showed that perceived usability in ecommerce is effective on the intention of using it. On the other hand, this finding is matched with the finding of Yang et al. (2011) which emphasized the role of perceived usefulness for resending electronic messages.

8. The perceived facility of usage of customer is related to his/her intention for involvement in viral marketing. Since Factor variable path of perceived facility of usage of customer to his/her intention for involvement in viral marketing is calculated with $t$ value, this statistic is significant with 0.95 and the eighth hypothesis is confirmed. Thus, the perceived facility of usage of civil engineers and architects of engineering council of Isfahan is related to their intention for engaging in viral marketing. This finding is matched with the finding of Yang et al. (2011) which was based on resending text messages. On the other hand, the chain of attitude, intention, and doing the action or resending messages is confirmed by Palka et al. (2009).

9. The intention of customer is related to his/her actual usage (acceptance) in viral marketing. Since Factor variable path of intention of customer to his/her actual usage for involvement in viral marketing is calculated with $t$ value, this statistic is significant with 0.95 and the ninth hypothesis is confirmed. Thus, the intention of civil engineers and architects of engineering council of Isfahan is related to their actual usage for engaging in viral marketing. That indicates that the intention of the people is effective on their practical involvement in viral marketing. This finding is matched with the finding of Yang et al. (2011) which both was based on resending text messages. On the other hand, the chain of attitude, intention, and doing the action or resending messages is confirmed by Palka et al. (2009).

The confirmation of hypotheses $4,5,6,7,8$ and 9 have resulted to the approval of technology Acceptance Model. Thus, the findings of this study are matched with the studies of Davis (1989), Venkatesh and Davis (2000) and Roberts (2000). Thus, according to the results of the hypotheses, we can find that the loyalty of civil engineers and architects of Engineering Council of Isfahan is related to their acceptance of viral marketing and their practical involvement in viral marketing.

\section{Research Limitations}

1. There have been a lot of researches related to viral marketing. It is not claimed in this research that all these studies have been explored.

2. The other limitation of this research is related to its domain. This research is limited to send and receive of text messages based on email. Although email is one of the most common tools of viral marketing, other tools are also considered. Each tool can have several aspects in terms of research.

3. The case study of this research is related to Engineering Council of Isfahan. Thus, the results cannot be generalized for all the users of this industry or other fields of this industry.

4. For collecting the data, a questionnaire was used but it seems that combination of quantitative data of questionnaire and qualitative data of calculations could lead to more valid and reliable results, and decrease Unintended biases.

5. Technology acceptance model used in this research is very common, and it was confirmed several times by researchers. Surely, not limiting the research to this model and using other technological models with new variables can be more efficient. 


\subsection{Recommendation for further research}

1. Today, the expanding influence of Internet and electronic interactions causes that companies increase their advertising and marketing plans. Therefore, investment on viral marketing as a solution with high potentiality is recommended. Although, studies have revealed that large multinational corporations use releasing of viral marketing extensively, it seems that small corporation especially in Iran use this method less, it is necessary to pursue this method more.

2. This showed that customers, attitude toward their intention to engage in viral marketing is positive, so the company must respond to this demand and with planning and designing campaigns for viral marketing, take advantage of the benefits of this level of willingness of consumers. In other words, other opportunities must be provided for clients who are involved in viral marketing and support of active consumers in different ways is strongly recommended.

3. This loyalty is a factor in the challenging virtual environment (Eckler \& Rodgers, 2010) affecting consumer involvement in viral marketing identified in the message content. As a result, companies that are designing viral marketing campaigns, have to seriously and actively seek to strengthen customer loyalty by creating and maintaining a closer relationship with customers. In this case, there must be better attitudes and more willing to engage customers in the shop viral content, and therefore the chances of success greatly increases in viral marketing campaigns.

4. Since this study showed that the perceived usefulness of consumers could predict their attitudes for engagement in viral marketing and their intention, it is recommended to the designers of viral marketing camps to increase the performance and usefulness of viral contents from the perspective of customers. This means that customers should understand that involvement in this case is beneficial for them. This requires special attention in designing viral content in a way that customers would not feel that their involvement is wasting of time or merely in the scope of benefits of company. On the other hand, another negative aspect of viral marketing is creating negative attitude in customers as they think that they are abused. Thus, avoiding such a kind of feeling, the designers of viral contents spend enough time and cost to provide useful content for them. On the other hand, this research confirmed that the perceived facility of usage is effective on the perceived usefulness of that. So, to make a viral content more practical and useful for the users, it is suggested that its involvement must be easy.

5. This research showed that the perceived usefulness is effective on the attitude of customers for engaging in viral marketing. Thus, it is reemphasized that it must be easy to access. These contents shall be opened easily and rapidly, read it and send it. Thus, the designers must know that it must be accessible with the fewest clicks. It must have low capacity, and it must be shown easily by common software. In brief, designers must increase the perceived usefulness, their attitude and customer loyalty by innovative methods on that specific field and specific customer.

\section{Acknowledgement}

The authors would like to thank the anonymous referees for constructive comments on earlier version of this paper.

\section{References}

Ajzen, I. (1991). The theory of planned behavior. Organizational behavior and human decision processes, 50(2), 179-211.

Davis, F.D. (1989). Perceived usefulness, Perceived ease of use, and user acceptance of information technology. MIS Quarterly, 13(3), 319-340.

Day, G. S. (1969). A two-dimensional concept of brand loyalty. Journal of Advertising Research, 9, 29-35.

Eckler, P., \& Rodgers, S. (2010). Viral Marketing on the Internet. Wiley International Encyclopedia of Marketing. John Wiley \& Sons Ltd. 
Fishbein, M., \& Ajzen I. (1975). Belief, attitude, intention, and behavior: an introduction to theory and research. Reading, USA: Addison-Wesley.

Ho, J. Y., \& Dempsey, M. (2010). Viral marketing: Motivations to forward online content. Journal of Business Research, 63(9), 1000-1006.

Houman, H.A. (2005). Structural equation modeling using LISREL. In Persian.

Hubona, G.S., \& Burton J.A. (2003). Modeling the user acceptance of E-mail. Proceedings of the Thirty-sixth Annual Hawaii International Conference on System Sciences (HICSS).

Jacoby, J., \& Chestnut, R.W. (1978). Brand Loyalty: Measurement Management. New York: John Wiley \& Sons.

Jan Nesar Ahmadi, H., \& Ghafari, M. (2007). Viral Marketing, cell-to-cell movement, Tadbir publication, 183, 48-46. In Persian.

Maghsoudi, M.H. (2003). The relationship between customer satisfaction with the efficiency and effectiveness of processes, Tehran: Proceedings of the Fourth Conference on Quality Management. In Persian.

Masouleh, S., Pazhang, M., \& Moradi, J. (2012). What is Impulse Buying? An analytical network processing framework for prioritizing factors affecting impulse buying. Management Science Letters, 2(4), 1053-1064.

Oliver, R. L. (1999). Whence consumer loyalty? the Journal of Marketing, 63, 33-44.

Palka, W., Pousttchi, K., \& Wiedemann, D. G. (2009). Mobile word-of-mouth-A grounded theory of mobile viral marketing. Journal of Information Technology, 24(2), 172-185.

Pavlov, O. V., Melville, N. P., \& Plice, R. K. (2005). Mitigating the tragedy of the digital commons: The problem of unsolicited commercial e-mail.Communications of the Association for Information Systems, 16, 73-90.

Roberts, P., \& Henderson, R. (2000). Information technology acceptance in a sample of government employees: a test of the technology acceptance model. Interacting with Computers, 12(5), 427-443.

Venkatesh, V., \& Davis, F. D. (2000). A theoretical extension of the technology acceptance model: Four longitudinal field studies. Management science, 46(2), 186-204.

Yang, H., Liu, H., \& Zhou, L. (2012). Predicting young Chinese consumers' mobile viral attitudes, intents and behavior. Asia Pacific Journal of Marketing and Logistics, 24(1), 59-77.

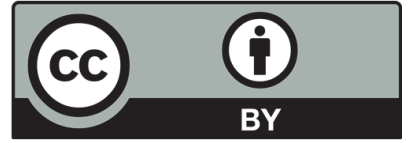

(C) 2016 by the authors; licensee Growing Science, Canada. This is an open access article distributed under the terms and conditions of the Creative Commons Attribution (CC-BY) license (http://creativecommons.org/licenses/by/4.0/). 